\title{
EFFECTS OF WATER ABSTRACTION AND POLLUTION ON MA- CROINVERTEBRATE COMMUNITY IN A MEDITERRANEAN RIVER
}

\author{
I. Muñoz \& N. Prat \\ Dept. Ecologia. Universitat de Barcelona. Av. Diagonal, 645. 08028 Barcelona, Spain.
}

Key words: discharge reduction, organic pollution, macroinvertebrate community, Mediterranean river.

Palabras clave: reducción de caudal, contaminacidn orgánica, macroinvertebrados, rio mediterráneo.

\begin{abstract}
The Llobregat is a Mediterranean river interrupted along its channel by a series of small dams which serve to divert water, and as a result of which, there are daily changes and severe reductions in discharge in many reaches of the river. Its watershed is, moreover, densely populated and industrialized with many point and diffuse pollution sources. Macroinvertebrate community was studied at three stations located in the middle reach of the Llobregat river during spring of 1991, 1993 and 1994 in order to observe the effect of reduced discharge and point-source pollution. A highly significant reduction of macroinvertebrate density and taxon number was observed at the disturbed stations. This pattern was similar for the most sensitive families. Erpobdellidae and Ancylidae were the only families favoured by the altered conditions.
\end{abstract}

\section{INTRODUCTION}

Mediterranean rivers have suffered pollution and water abstraction for several centuries and this trend has steadily increased in recent years, especially in countries undergoing rapid growth. Many rivers and streams have dried up or been polluted because of the increase in water use.

The flow fluctuations induced by changes in the water abstraction regime can produce important adverse effects on fluvial communities (WARD \& STANDFORD, 1979; ARMITAGE, 1984; ARMITAGE $\boldsymbol{e}$ t al., 1987; Petts, 1984). In general, unnatural rapid increases and decreases in water volume cause changes in species composition and alterations in life cycles and population abundances.

Numerous studies have attempted to assess the effects of organic pollution on macroinvertebrate community. Such water body enrichment usually changes the community structure when the most sensitive species disappear and increase the relative abundance of the more tolerant groups (MASON, 1991).

Physico-chemical characteristics and macroinvertebrate communities in the Llobregat river have been described by several workers (PRAT et al. 1984, PRAT \& WARD, 1994; MUÑOZ\& PRAT, 1992, 1994) and most of these draw particular attention to the range of disturbances, mainly produced by humans. Continuous disturbances in the last 10 years have resulted in more than $3 / 4$ of the river with highly stressed community.

The object of this work is to test the effect on the macroinvertebrate community of reduced discharge and point-source pollution in a reach of the river in which a control zone (nearly constant but regulated discharge and no pollution) can be defined.

\section{STUDY SITE}

The Llobregat is a Mediterranean river with karstic springs in the NE of Spain. The main channel is $145 \mathrm{~km}$ long and its drainage basin has an area of $4,948 \mathrm{~km}^{2}$. The river flow is regulated in the upper part by La Baells dam with a storage capacity of $125 \mathrm{Hm}$. Two of the most important characteristics of the Llobregat basin are the existence of numerous weirs and the high concentration of pollutants in the water both of which become more apparent downstream. The main channel of the Llobregat is continuously interrupted by a serie of small dams which divert water to small hydroelectric power stations and as a result, several reaches of the river have a very low discharge or are totally dry. Hydroelectric power generation can therefore produce daily changes in the discharge and the river 
water level. The Llobregat watershed is densely populated with many sources of pollution along the river (e.g. textile and papermill industries, agriculture, livestock and mining) and sewage discharge is frequent.

Three sampling stations were located in the upper part of the middle reach of the river (fig. 1) to measure the effect of changes in river water flow due to the presence of weirs, and wastewater discharge from the town of Berga (13,766 inhabs.), on the macroinvertebrate community.

The first sampling point (st. 1) was established as the control station and was located $35 \mathrm{~km}$ from the source of the Llobregat. At this point the river is in fairly good conditions, although the water is rich in nutrients because of its hypolimnetic origin from La Baells dam (table 1) there is no great changes in water quality leading to an increase in the abundance of intolerant insects species. Moreover the river flux is nearly constant (aprox. $2 \mathrm{~m}^{\prime} \mathrm{s}^{1}$ ).

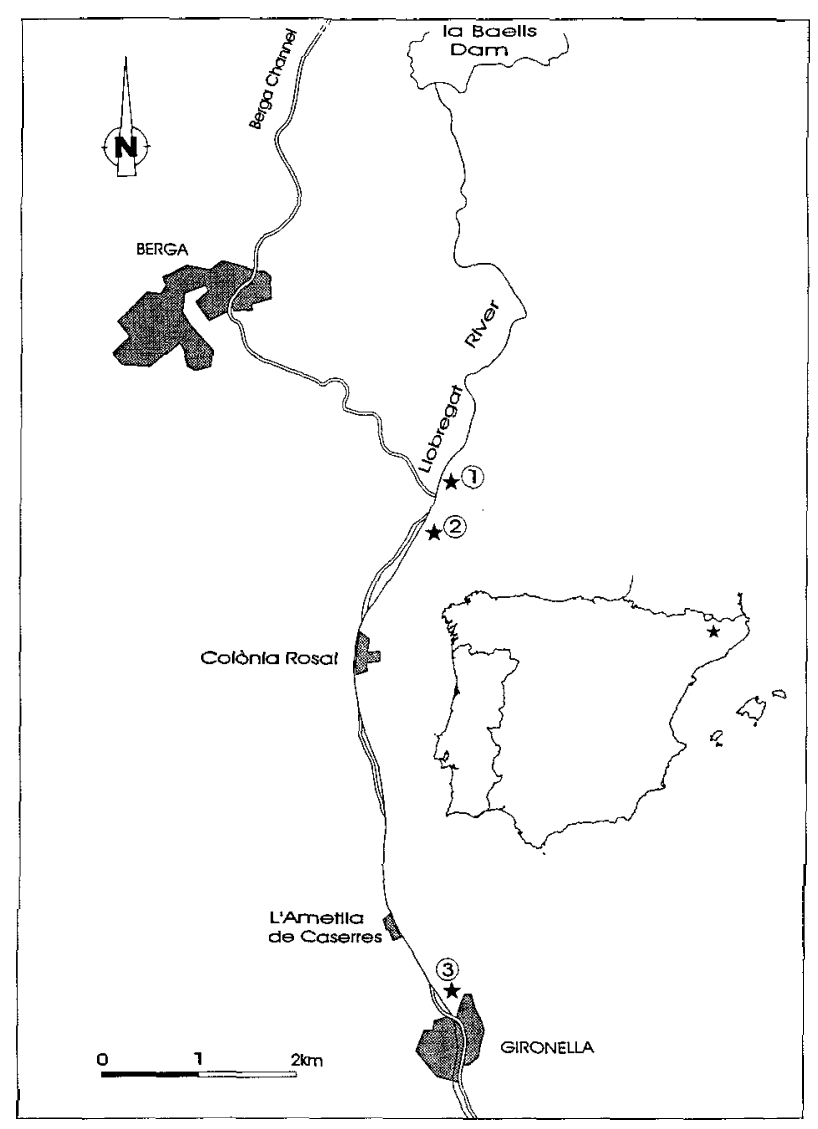

FIGURE I. Situation of the Llobregat river, NE Spain, and the sampling sites analyzed in this study.

FIGURA I. Situación del río Llobregat, NE de España, y de los lugares de muestreo analizados en erte estudio.
TABLE I. Mean values of physico-chemical parameter-s at sampling statıons Data of sites 2 and 3 are only for 1991 . except discharge.

TABLA 1. Valores medios de los parámetros fisico-quirnicos en las estaciones de muestreo. Excepto para la descarga, los datos de los sitios 2 y 3 son solo para 1991.

\begin{tabular}{lccc}
\hline & STATION 1 & STATION 2 & STATION 3 \\
\hline CONDUCTIVITY $(\mu \mathrm{S} / \mathrm{cm})$ & $522.2 \pm 47$ & 685 & 450 \\
TEMPERATURE $\left({ }^{\circ} \mathrm{C}\right)$ & 9.1510 .6 & 117 & 11.5 \\
OXYGEN $(\mathrm{mg} / \mathrm{l})$ & $10.6 \pm 0.7$ & 102 & 9.7 \\
TOTAL SUSPENDED & & & \\
SOLIDS $(\mathrm{mg} / \mathrm{l})$ & $3.3 \pm 2.0$ & 10.0 & 257.3 \\
& & & 2.18 \\
Ortho-PO43- $(\mu \mathrm{M})$ & $0.17 \pm 0.12$ & 0.27 & 13.8 \\
NH4+-N $(\mu \mathrm{M})$ & & & \\
CHLOROPHYLL a $\left(\mathrm{mg} / \mathrm{m}^{2}\right)$ & 792 & 725 & 205 \\
& & & \\
DISCHARGE $\left(\mathrm{m}^{3} / \mathrm{s}\right)$ & $2.5 \pm 0.5$ & $0.5 \pm 0.5$ & $0.02 \pm 0.005$ \\
& & & \\
\hline
\end{tabular}

Station 2 was located $2 \mathrm{~km}$ downstream from a small hydroelectric power dam. Between stations 1 and 2 water coming from Berga is channelled into the river with mean discharge of $2 \mathrm{~m}^{\prime} \mathrm{s}^{1}$ and maximum discharge of $4 \mathrm{~m} \mathrm{~s}^{2}$. The water from the Berga channel, diverted from the river upstream of La Baells dam, was found to have high concentrations of suspended solids and to receive pollution from the village and surrounding industries. However, the mixed water of the channel and the river is diverted I $\mathrm{km}$ upstream from station 2 and, therefore, station 2 receives only part of this water. As a result, this station is heavily affected by reduced discharge but only slightly by pollution as shown the low differences of ammonia and phosphorous concentrations in the water (table 1).

The third station was located $6 \mathrm{~km}$ downstream from station 2. Two hundred meters upstream from the station a weir diverts nearly all the water from the river. At this station, water contains a high concentration of suspended solids (table I) in addition to pollution inputs from Berga city (table 1) which were discharged to Llobregat through a small tributary downstream of station 2. At the three sampling sites substrate is mainly composed by cobbles and stones, slope is similar and the channel width is nearly $10 \mathrm{~m}$. 


\section{MATERIAL AND METHODS}

The three stations were sarnpled in May 1991, April 1993 and April 1994. Water samples were taken to measure several physical and chemical parameters: conductivity, temperature, suspended solids concentration, oxygen concentration, orthophosphate and ammonia concentrations. Renthic chlorophyll a concentration was also measured, by taking samples of $2 \times 2 \mathrm{~cm}^{2}$ from different stones, using the spectrophotometric routine. Flow data were provided by Junta d' Aigues (Generalitat de Catalunya).

The macroinvertebrate fauna was collected using individual stones as unit sample. Ten individual cobbles were picked up randomly from the river bed. Their surface area was measured by wrapping thern in aluminum foil and estimating the area by its weight. Three linear measurements of each stone were also taken. Both estimates were used to develop an equation for calculating the surface area of newly sampled stones (sec MUÑOZ \& PRAT, 1994). This method has frequently been used to express the number of organism per unit area (WRONA et al. 1986; GRAHAM et al. 1988, DOWNES et al. 1993).

Collections were fixed in the field with $4 \%$ formaldehyde, macroinvertebrate organisms were sorted and identified to family level in the laboratory. This degree of taxonomic accuracy has been found to be satisfactory for general biological quality assessment (FURSE er al. 1984, ARMITAGE et al. 1994).

Differences in individual macroinvertebrate density and number of taxa between sampling stations and years were analyzed using a two-way ANOVA. All data were logarithmically transformed to stabilize variances. Where difference were detected $(p<0.05)$, a Tukey HSD (Honest significant diference) test (SPJOTVOLL \& STOLINE, 1973) was employed to determine which sites were significantly different. This test is a more conservative procedure and applicable in a relatively broad class of situations. All statistical analyses were performed using a PC version of the CSS-Statistica.

\section{RESULTS}

\subsection{Physico-chemical characteristics}

At station 2 a small increase was recorded in orthophosphate and suspended solid concentration with respect to the control (table 1). Temperature at this station was $3^{\circ} \mathrm{C}$ higher than at station I due to the low discharges induced by the weirs.

At station 3 the effect of the polluted waters originating in the town of Berga is more evident, with a significant increase in orthophosphate concentration (from $0.17 \mu \mathrm{M}$ at station I, to $2.18 \mu \mathrm{M}$ at this station) and in suspended solids concentration (from $4.3 \mathrm{mg} \mathrm{l}$ ' to $257.3 \mathrm{mg} 1^{1}$ ). Ammonia concentration is 1.28 $\mu \mathrm{M}$ at station 1 and 2 and increases to $13.5 \mu \mathrm{M}$ at station 3 .

The increase of suspended solids in the water seems to affect primary producers directly because the benthic chlorophyll-a concentration at station 3 is reduced to half of concentration at stations 1 and 2 (table 1).

We show data from the three years studied only at station I (table I). Data from sites 2 and 3 in 1993 and 1994 were similar to 1991 comparing our data with data provided by Aigues de Barcelona, one of the public water authorities.

\subsection{Macroinvertebrate community.}

Twenty-eight different families were identified at the three stations in the three years under study, twenty-two families were present at station 1 , twenty at station 2 while the number of families at station 3 fell to eleven. The most abundant families were the Oligochaeta Naididae, the Coleoptera Elmidae, the Trichoptera Rhyacophilidae, Hydropsychidae and Hydroptilidae and the Diptera Chironomidae, Simuliidae and Empididae.

The total individual density per stone area decreases significantly at the disturbed stations (table 2, 3). At station 1 mean values ranged from 4,260 to 26,082 ind $\mathrm{m}^{-2}$. The effect of low water discharge reduces this density between 953 to 7,198 at station 2 and from 527 to 3,136 at station 3 where the effect of wastewater produces a further reduction of macroinvertebrate density. This decrease in density is observed in almost all the taxa.

Global macroinvertebrate abundance also varied significantly between years, abundance was lower in 1993 and 1994. The general sampling station pattern of abundance remained consistent in 1991 and 1993, while in 1994 station 2 had lower densities than station 3 (table 2, 3)

The mean number of families per sample ranged from 4 to 14 (table 2) and also showed highly significant variation between stations and years (table 3). The number of taxa was significantly low downstream from the altered stations (stations 2 and 3) and in the years 1993 and 1994.

TABLE 2. Mean and standard deviation of macroinvertebrate abundance and number of families at the three sampling stattons and in the years under study. TABLA 2. Medias y desviaciones standard de las abundancias y número de familias de macro-invertebrados en lac tres estaciones de muestreo durante los años de estudio.

\begin{tabular}{|c|c|c|c|}
\hline & STATION 1 & STATION 2 & STATION 3 \\
\hline 1991 indiv/m ${ }^{2}$ & $26082 \pm 9494$ & $7198-2175$ & $2473 \pm 1047$ \\
\hline number of taxa & $137 \pm 27$ & $11.0 \pm 1.4$ & $52-t 21$ \\
\hline 1993 indiv/m ${ }^{2}$ & $4260 \pm 2586$ & $1694 \pm 1697$ & $527 \pm 371$ \\
\hline number of taxa & $7.7 \pm 1.3$ & $7.0 \pm 1.6$ & $4.3 \pm 1.1$ \\
\hline 1994 indiv $/ \mathrm{m}^{2}$ & $9125 \pm 13362$ & $953 \pm 455$ & $3136 \pm 2673$ \\
\hline number of taxa & $8.8 \pm 25$ & $6.3+11$ & 4.011 .0 \\
\hline
\end{tabular}


TABLE 3. Results of two-way ANOVA and Tukey HSD test for abundance of dominant taxn. number of individuals and number of taxa. Stations or years joined by the same line or marked by $\left({ }^{\circ}\right)$ were not significantly different $n s=$ not significant; $*=p<0.05 ; * *=p<0.001:{ }^{\circ}+{ }^{-}-p<0.0001$

TABLA 3. Resultados de los test de ANOVA y HSD de Tukey para la abundancia de taxones dominantes. número de individuos y número de taxones Las estaciones 0 años unidos por la misma línea o marcados con (o) no mostraron diferencias significativas ns=no significativo; $*=0.05 ; * ;: p<0.001, * *:=p<0.0001$

\begin{tabular}{|c|c|c|c|c|c|}
\hline & Stations & $\mathrm{F}$ value & Years & & $\mathrm{F}$ value \\
\hline Naididae & $\begin{array}{lll}1 & 2 & 3\end{array}$ & $4.14 \mathrm{~ns}$ & $1991 \quad 1993$ & 1994 & $24.89^{* * *}$ \\
\hline Erpobdellidae & 123 & $21.91 * * *$ & $\underline{1991 \quad 1994}$ & 1993 & $9.77^{* * *}$ \\
\hline Hydrobiidae & $\begin{array}{lll}1 & 2 & 3\end{array}$ & $0.99 \mathrm{~ns}$ & $1991 \quad 1993$ & 1994 & $7.17^{*}$ \\
\hline Ancylidae & 123 & $15.69^{* * *}$ & 19911993 & 1994 & $2.60 \mathrm{~ns}$ \\
\hline Baetidae & $1 \quad 2 \quad 3$ & $5.66^{*}$ & $1991 \quad 1993$ & 1994 & $0.61 \mathrm{~ns}$ \\
\hline Ephemerellidae & 123 & $2.85 \mathrm{~ns}$ & 19911993 & 1994 & $1.35 \mathrm{~ns}$ \\
\hline Perlidae & 123 & $11.59^{* * *}$ & $1991 \quad 1994$ & 1993 & $4.89^{*}$ \\
\hline Elmidae & 123 & $17.13^{* * *}$ & $\underline{1991 \text { 1993" }}$ & 1994" & 7.52 ** \\
\hline Rhyacophilidae & $\underline{12} 3$ & $8.24^{* * *}$ & $\underline{1991 \quad 1993 "}$ & $1994 "$ & $8.24^{* * *}$ \\
\hline Hydroptilidae & $\begin{array}{lll}1 & 2 & 3\end{array}$ & $0.81 \mathrm{~ns}$ & $1991 \quad 1993$ & 1994 & $7.41 *$ \\
\hline Hydropsychidae & 123 & $7.21 *$ & $1991 \underline{1993}$ & 1994 & $28.97 * * *$ \\
\hline Polycentropodidae & $\begin{array}{lll}1 & 2 & 3\end{array}$ & $1.74 \mathrm{~ns}$ & 19911993 & 1994 & $1.71 \mathrm{~ns}$ \\
\hline Sericostomatidae & 123 & $1.34 \mathrm{~ns}$ & $1991 \quad 1993$ & 1994 & $0.76 \mathrm{~ns}$ \\
\hline Limnephilidae & $\begin{array}{lll}1 & 2 & 3\end{array}$ & $3.03 \mathrm{~ns}$ & $\underline{1991 \quad 1994 "}$ & 1993" & $5.54 *$ \\
\hline Simuliidae & $1 \quad 2 \quad 3$ & $6.58^{*}$ & 19911993 & 1994 & $3.34 \mathrm{~ns}$ \\
\hline Chironomidae & $12^{\circ} 3^{\circ}$ & $4.49^{*}$ & $1991 \quad \underline{1993}$ & 1994 & $18.42^{* * *}$ \\
\hline Ceratopogonidae & $12^{\circ} 3^{\circ}$ & $3.97^{*}$ & 19911993 & 1994 & $1.84 \mathrm{~ns}$ \\
\hline Empididae & $1 \quad 2 \quad 3$ & $15.32^{* * *}$ & $\underline{1991 \quad 1994^{\circ}}$ & $1993^{\circ}$ & $8.71^{* * *}$ \\
\hline Number of individuals $/ \mathrm{m}^{2}$ & 123 & $22.43^{* * *}$ & $1991 \underline{1993}$ & 1994 & $32.76^{* * *}$ \\
\hline Number of taxa & $\begin{array}{lll}1 & 2 & 3\end{array}$ & $31.54^{* * *}$ & $1991 \quad 1993$ & 1994 & $22.23^{* * *}$ \\
\hline
\end{tabular}

\subsection{Spatial changes}

Despite differences between years (which will be analysed later), several similarities appear in density changes between stations.

Most families decreased in density at the disturbed stations, this being the general trend followed by the community and this decrease is only significant in the most sensitive taxa. Abundance of the ephemeroptera Baetidae and the diptera of the families Empididae and Simuliidae, showed a significant decrease when discharge dropped at stations 2 and 3 (fig. 2, table 3). The trichopterans Rhyacophilidae and Hydropsychidae and the coleoptera Elmidae arc heavily affected by pollution (station 3 ) but less so by decreasing rtver flow (fig. 2) as showed no significant differences between station 1 and 2 (table 3 ).

The family Perlidae (primarily Dinocras), were never found at station 3, highlighting the importance of pollution at this site. The density of this family was not significantly different at stations 1 and 2 (table 3). The diptera Ceratopogonidae was present, with low abundance, at stations 1 and 2 but was also absent from station 3. This low abundance explained the nonsignificant differences between stations using the Tukey test.

In other cases, the trend is reversed, with increasing densities downstream. The mollusca Ancylidae (Ancylus fluviatilis) shows significant change between stations (table 3 ), increasing at station 3 (fig. 2). The Erpobdellidae (Dina lineata) varies significantly among stations. The number of individuals increases greatly at station 3 while its presence went unrecorded at station 1 (fig. 2).

In those cases in which the densities were low there is no significant trend between stations. As an example, we can see the erratic behaviour of the Hydrobiidae Potamopyrgus antipodarum or the mayfly of the family Ephemerellidae (fig. 2 , table $\mathbf{3}$ ). Both present a reduced density at station $\mathbf{3}$, though 

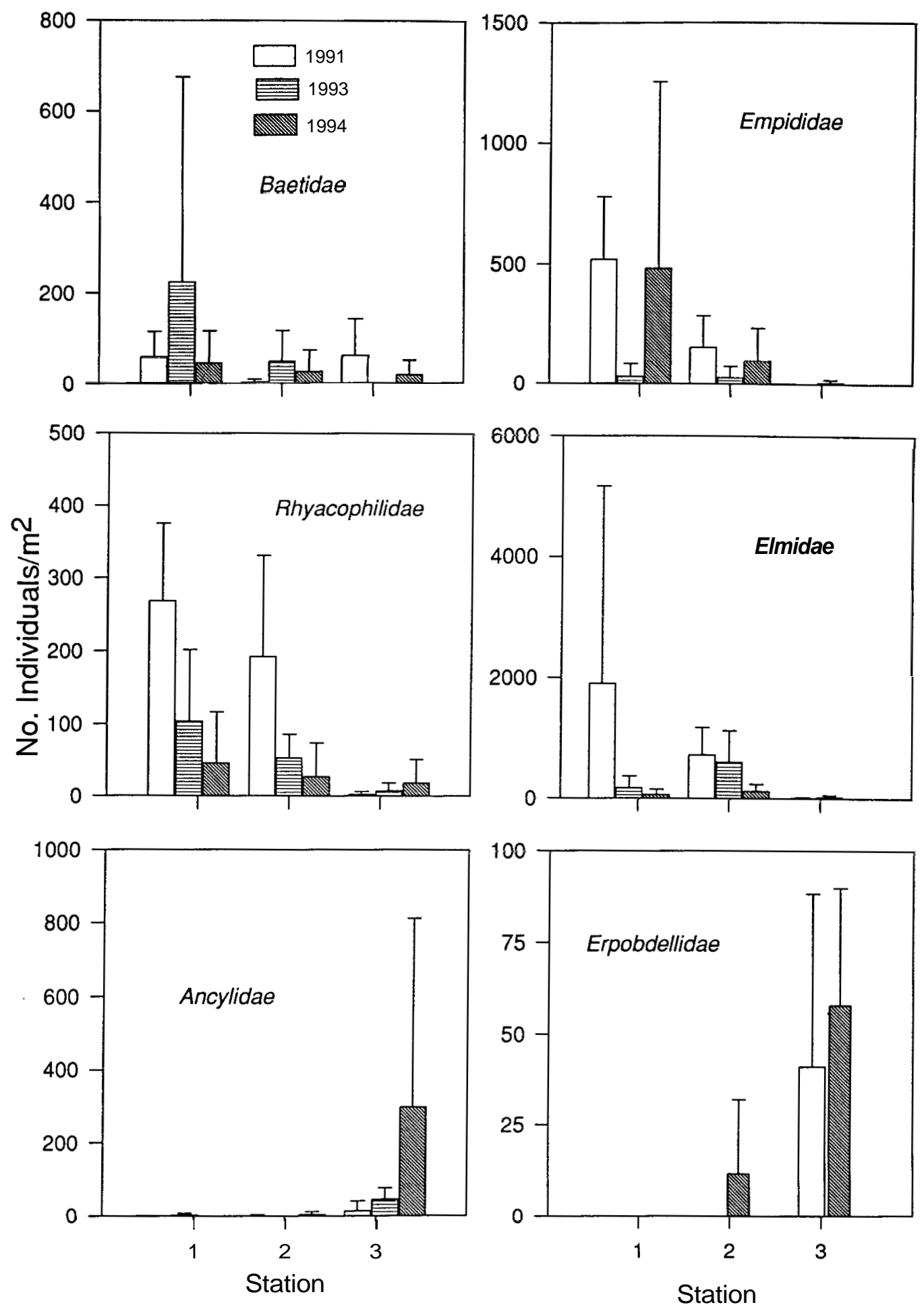

FIGURE 1. Simulation of the Llobregat river, NE Sapin, and the sampling sites analyzed in this study

FIGURA 1. Simulación del río Llobregat, NE de España, y de las estaciones de rnuestreo analizadas en este estudio. 

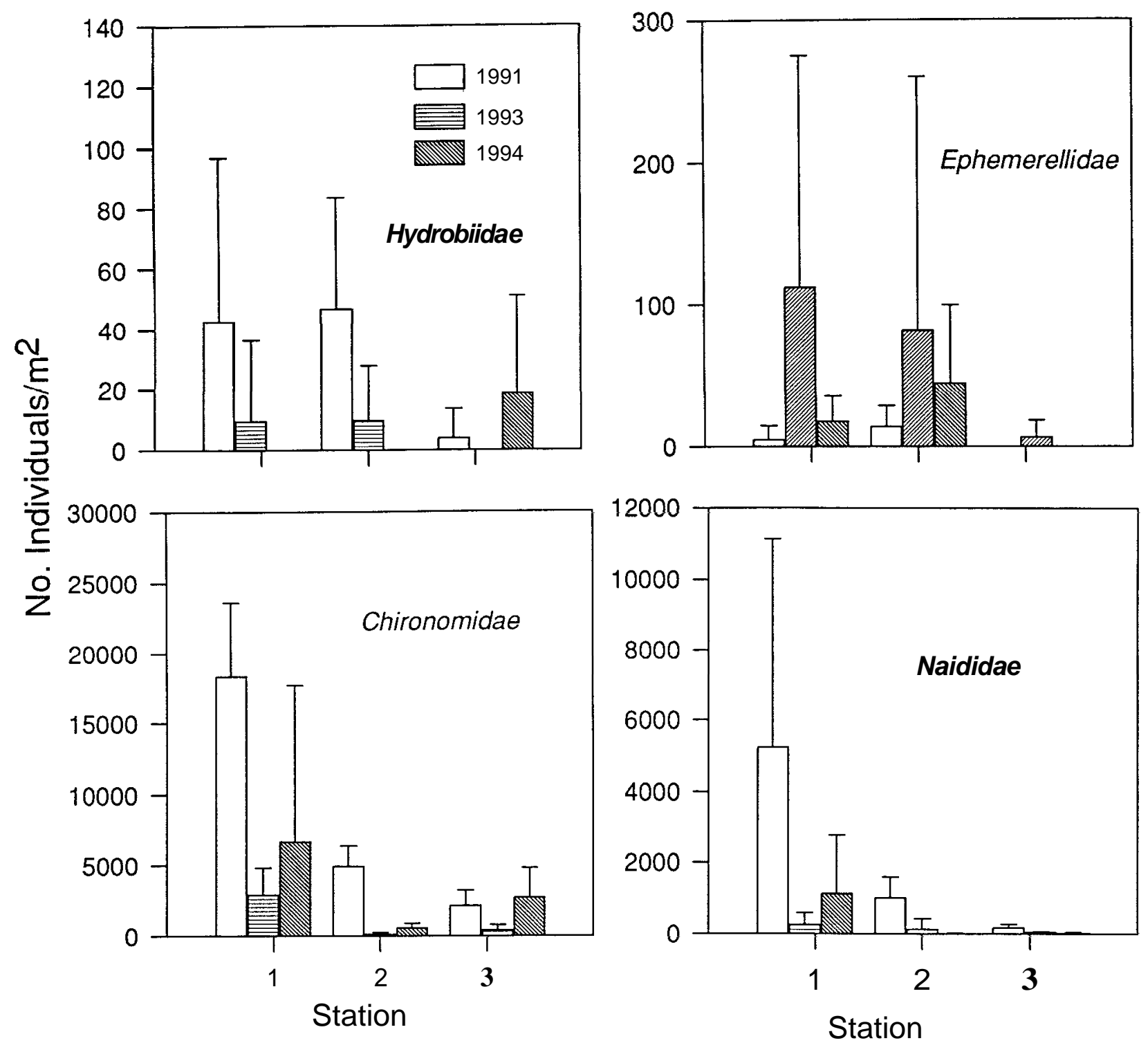

FIGURE 2 Mean abundance and standard deviation $(\mathrm{N}=10)$ of the indicated families at sampling stations during the three years of the study.

FIGURA 2. Abundancia media y desviación standard $(\mathrm{N}=10)$ de las familias indicadas en las estaciones de muestreo durante los tres años del estudio

not statistically significant, while the pattern is different between years. Wright ct al. (1984) pointed out that Potamopyrgus jenkinsi (synonymous with P. antipodarum) showed a wide range of distribution patterns, being present both at sites with continous flow and intermittent flow sections.

\subsection{Temporal changes}

The most abundant families, such as Chironomidae or the oligochaeta Naididae, indicate the general temporal trend of the community. Large numbers of individuals from both families were collected during 1991 with respect to 1993 and 1994 (fig. 2, table 3). This pattern of abundance was also 
recorded for other families like Hydrobiidae, Elmidae and the three most abundant trichopterans: Rhyacophilidae, Hydroptilidae and Hydropsychidae (table 3).

However, other groups show a distinct temporal behaviour. For example, the diptera Empididae presented its lowest abundance in 1993, increasing again in the next year. Something similar occurs with the leech of the family Erpobdellidae; no individual of this family was found in 1993 (fig. 2). In contrast in the same year, the density of Perlidae showed a significant increase (table 3), decreasing in 1994 to levels similar to those recorded in 1991. The trichoptera Limnephilidae occurred at an uncommonly high abundance in 1993 but was practically absent in 1991 and 1994.

\section{DISCUSSION}

The principal factors influencing the physical, chemical and hydrological features of the water in this part of the Llobregat river are flow modification from weirs and pollution from the Berga channel and the sewage input of this town. These factors seem to have direct impacts on the community.

Organic pollution in this reach of the Llobregat river combines with high levels of suspended solids that may cause various direct (on the organism) and indirect (modifiying the aquatic habitat) effects on the aquatic community (WARD, 1992; DAVIES-COLLEY et al., 1992).

The weirs constructed for water diversion have supplanted most of the riverine environment with pool habitats and have interrupted the continuity of the littoral zone (WALKER et al., 1992). All this may be a fundamental reason for the general decline of the community. ARMITAGE et al.(1994, 1987), GARCIA DE JALON \& SANCHEZ (1994), WOOD \& PETTS (1994) observed alterations in the structure of the benthic macroinvertebrate community because of the environmentally catastrophic conditions caused by short-term flow fluctuations.

The community in the study section is dominated numerically by opportunistic taxa of small size and short generation time (mainly Oligochaeta and Chironomidae). This pattern is consistent with the behaviour of a stressed ecosystem (ODUM, 1985) and could be generalized for a long stretch of the Llobregat river (PRAT et al., 1983).

Our ANOVA results indicated significant differences in density and number of taxa between sampling stations and years. The community shows a pattern of reduced abundance and richness at the disturbed stations and during the sampling period. The progressive damage in the community could be the result of a parallel decrease in environmental quality.
A comparison of major group abundances at stations upstream and downstream from the perturbation suggested that some families were significantly affected by water abstraction or pollution. Mayflies of the family Baetidae are the most sensitive to change in discharge and water quality from stations 2 and 3. Abundance of Baetidae is the lowest at these perturbed stations. The dipterans Empididae and Simuliidae show a similar pattern. The low abundance of the filter-feeder blackflies could be related to Flow changes and reduced food availability. The greatest seston supply found in areas of high velocity and turbulence favours filter-feeders (QUINN \& HICKEY, 1994; WETMORE et al., 1990), conditions not found at stations 2 and 3.

Physico-chemical water changes at station 3 cause a reduction in density of several groups. Plecoptera disappear at this site and the trichopterans Rhyacophilidae and Hydropsychidae as well as Elmidae account for very few individuals. The high increment of suspended solids at station number 3 and the decrease in the ratio organic: inorganic material (MUÑOZ \& PRAT, 1992) involve a severe change on the quality and quantity of the Food supply (QUINN et al.. 1992) for filter-feeders, such as Hydropsyche, which in addition suffer obstructed nets due to the excess of suspended solids.

Compared with other macroinvertebrate behaviour, the leech of the family Erpobdellidae and the mollusc A. fluviatilis are the only taxa Favoured by the fall in discharge and in particular by pollution.

Benthic chlorophyll-a concentration on the stones decreases with the increase of suspended solids in the water because of a loss of water transparency. Under these conditions, frequent and rapid changes in water level represent an additional disturbance for the periphyton. The decrease in algae density reduces the depuration capacity of the river while the increment of detritus and the inert solid content on the periphyton is also known to influence invertebrate growth and fecundity.

Also, discharge variability and organic enrichment decrease the density, richness and complexity of the macroinvertebrate community this results in a loss of the capacity to recycle organic matter present in the river and a further seduction in water quality.

These problems can be extended to all of the river Llobregat because of the continuous presence of weirs supplying water for electricity generation and the wastewater contributions from its highly populated watershed.

In the future, the closing of mining activities and the operation of a sewage plant in Berga, should contribute to better environmental conditions at station 3 , although reduced flow will still affect part of the community. 


\section{ACKNOWLEDGEMENTS}

Macroinvertebrate sorting and identifiying was performed by N. Solé and M. Sabadell in 1991 and by students on the 1993 and 1994 limnology course. We would like to thank Servei d' Assessorament Linguistic of Universitat de Barcelona for reviewing the English. Financial assistance was partly provided by Junta de Sanejament of Generalitat de Catalunya.

\section{REFERENCES}

ARMITAGE. P.D.. 1984. Environmental changes induced by stream regulation and their effects on lotic macroinvertebrates communities. In: LILLEHAMMER, A. and SALTVEIT, S.J. (eds.). Regulated Rivers. University of Oslo, Oslo.

ARMITAGE, P.D., GUNN, R.J.M., FURST, M.T., WRIGHT, J.F. and MOSS, D., 1987. The use of prediction to assess macroinvertebrate response to river regulation. Hydrobiologia, 144, 25-32.

ARMITAGE, P.D., BLACKBURN, J.H., WINDER, J.M. \& WRIGHT, J.F., 1994. Impact of vegetation management on macroinvertebrates in chalk streams. Aquatic Conservation: Marine and Freshwater Ecosystems, 4, 95-104.

DAVIES-COLLEY, R.J., HICKEY, C.W., QUINN, J.M. \& RYAN, P.A., 1992. Effects of clay discharges on streams. 1. Optical properties and epilithon. Hydrobiologia, 248, 215-234.

DOWNES, B.J., LAKE, P.S. \& SCHREIBER, E.S.G., 1993. Spatial variation in the distribution of stream invertebrates: implications of patchiness for models of community organization. Freshwater Biology 30, 119-132.

FURSE, M.T., MOSS, D., WRIGHT, J.F. \& ARMITAGE, P.D., 1984. The influence of seasonal and taxonomic factors on the ordination and classification of running-water sites in Great Britain and on the prediction of their macroinvertebrate communities. Freshwater Biology 14, 257-280.

GARCÍA DE JALON, D. \& SÁNCHEZ, P., 1994. Downstream effects of a new hydropower impoundment on macrophyte, macroinvertebrate and fish communities. Regulated Rivers: Research and Management, 9, 253-261.

GRAHAM, A.A., McCAUGHAN D.J. \& McKEE, F.S., 1988. Measurement of surface area of stones. Hydrobiologia 157: 85-87.

MASON, C.F., 1991. Ecology of freshwater pollution (2nd ed.). Longman Scientific \& Technical. Longman Group UK Ltd.

MUÑOZ, I. \& PRAT, N., 1992a. Cambios en la calidad del agua de los ríos Llobregat y Cardener en los últimos diez aiios. Tecnología del Agua, 91: 17-23.

MUÑOZ, I. \& PRAT, N., 1992b. Canvis en la qualitat de les aigiies i les comunitats d'organismes com a conseqüència de la realització del col.lector de salmorres al riu Llobregat. Informe final per la Junta de Sanejament. Generalitatde Catalunya. 79 pp.
MUÑOZ, I. \& PRAT, N., 1994. A comparison between different biological water quality indexes in the Llobregat basin (NE Spain). Verh. Internat. Verein. Limnol., 25: 1945-1949.

ODUM, E.P., 1985. Trends expected in stressed ecosystems. BioScience, 35, 419-422.

PETTS, G.E., 1984. Impounded rivers: perspectives for ecological management. John Wiley \& Sons, Chichester, UK.

PRAT, N., PUIG, M.A. \& GONZÁLEZ, G., 1983. Predicció $i$ control de la qualitat de les aigiies del riu Besòs i Llobregat II: El poblament faunistic i la seva relació amb In qualitat de les aigiies. Monografies, 9. Publicacions del Servei de Medi Ambient de la Diputació de Barcelona.

PRAT, N., PUIG, M.A., GONZÁLEZ, G., TORT, M.J. \& ESTRADA, M., 1984. Llobregat. In: WHITTON, B.A. (ed.): Ecology of European Rivers: 527-552. Blackwell Scientific Publications, Oxford.

PRAT, N. \& WARD, J.V., 1994. The tamed river. In: MARGALEF R. (ed.): Lymnology now: A Paradigm of Planetary Problems. Elsevier Sciences B.V.

QUINN, J.M. \& HICKEY, C.W., 1994. Hydraulic parameters and benthic invertebrate distributions in two gravel-bed New Zealand rivers. Freshwater Biology, 32, 489-500.

SPJOTVOLL, E. \& STOLINE, M.R., 1973. An extension of the T-method of multiple comparison to include the cases with unequal sample sizes. Journal of the American Statistical Association, 68, 976-978.

WALKER, K.F., THOMS, M.C. \& SHELDON, F., 1992. Effects of weirs on the littoral environmental of the river Murray, South Australia. In: BOON, P.J., CALOW, P. \& PETTS, G.E. (eds.), River Conservation and Management. John Wiley and Sons Ltd. USA.

WARD, J.V., 1992. Aquatic Insect Ecology. I. Biology and habitat. John Wiley \& Sons, Inc. USA.

WARD, J.V. and STANFORD, J.A. (eds.) 1979. The Ecology of Regulated Streams. Plenum Press, New York.

WETMORE, S.H., MACKAY, R.J. \& NEWBURY, R.W.. 1990. Characterisation of the hydraulic habitat of Brachycentrus occidentaiis, a filter feeding caddisfly. Journal of North American Benthological Society, 9, 157-169.

WOOD, P.J. \& PETTS, G.E., 1994. Low flows and recovery of macroinvertebrates in a small regulated chalk stream. Regulated Rivers: Research \& Management, 9, 303-316.

WRIGHT, J.F., HILEY, P.D., COOLING, D.A., CAMERON. A.C., WIGHAM, M.E. \& BERRIE. A.D., 1984. The invertebratefauna of a small chalk stream in Berkshire, England. and the effect of intermittent tlow.Arch. Hydrobiol., 99 (2): 176-199.

WRONA, F.J., CALOW, P., FORD, I., BAIRD, D.J. \& MALTBY, L., 1986. Estimating the abundance of stone-dwelling organisms: a new method. Can. J. Fish. Aquat. Sci. 43: 2025-2035. 